PENGARUH BAHAN ORGANIK DAN PUPUK NPK TERHADAP SERAPAN HARA DAN PRODUKSI JAGUNG DI INCEPTISOL TERNATE

\title{
The Effects of Organic Matter and $N, P, K$ Fertilizer on Nutrient Uptake and Yield of Corn in Inceptisol Ternate
}

\author{
Idris Abd Rachman1, Sri Djuniwati2 dan Komarudin Idris ${ }^{2}$ \\ 1 Program Studi Ilmu Tanah Fakultas Pertanian Universitas Khairun, Ternate \\ 2 Departemen Ilmu Tanah dan Sumberdaya Lahan, Fakultas Pertanian \\ Institut Pertanian Bogor Jalan Meranti Kampus IPB, Darmaga 16680
}

\begin{abstract}
The objective of the research was to study the effects of organic matter and $N, P, K$ fertilizer on nutrients uptake and yield of corn in Inceptisol Ternate. The design of the research was factorial completely randomized block design with two factors. The first factor was the rate of organic matter $(0,20,40 \mathrm{t} / \mathrm{ha})$ or $\left(B_{0,}, B_{1}\right.$ and $\left.B_{2}\right)$ and the second factor was the rate of $N, P, K$ fertilizer $\left(0.5 ; l\right.$ and 1.5 recommended rate) or $\left(F_{1}, F_{2}\right.$ and $\left.F_{3}\right)$.

The results of research showed that combination of $B_{1} F_{2}$ gave the highest amount of the corn leave at 42 days after planting, the weight of corn with husk cover, the weight corn grains, and K-availability of soil. Whereas, the rate of 20 tha organic matter $\left(B_{1}\right)$ significantly increased and gave the highest weight of corn without husk cover, NPK corn plant content and $P$ uptake. The average NPK plant uptake of corn was $31.41-39.39 \mathrm{~kg} \mathrm{~N} / \mathrm{ha}, 6.03-12.54 \mathrm{~kg} \mathrm{P} / \mathrm{ha}, 37.5-41.70 \mathrm{~kg} \mathrm{~K} / \mathrm{ha}$. The average production of corn was 5.16-7.83 t/ha.
\end{abstract}

Keywords : Organic matter, NPK fertilizers, nutrient, corn, yield, Inceptisols

\section{PENDAHULUAN}

Kesuburan tanah adalah suatu keadaan tanah dimana tata air, udara dan unsur hara dalam keadaan cukup, seimbang dan tersedia sesuai kebutuhan tanaman. Penggunaan pupuk merupakan suatu kebutuhan bagi tanaman untuk mencukupi kebutuhan nutrisi dan menjaga keseimbangan hara yang tersedia selama siklus pertumbuhan tanaman. Pemberian pupuk organik merupakan tindakan pengelolaan yang diharapkan dapat memperbaiki kesuburan tanah melalui perbaikan sifat fisik, kimia, dan biologi tanah. Beberapa penelitian menunjukkan pupuk organik dapat meningkatkan efisiensi pemberian pupuk anorganik yang pada gilirannya dapat menunjang produksi yang maksimal. Pemberian bahan organik dan pupuk anorganik (N, P dan K) merupakan suatu usaha dalam memenuhi kebutuhan hara bagi tanaman. Hal ini dimaksudkan untuk memperbaiki keseimbangan hara yang terdapat didalam tanah. Fungsi Bahan organik menurut Leiwakabessy et al (2003) adalah (1) memperbaiki struktur tanah, (2) menambah ketersediaan unsur $\mathrm{N}, \mathrm{P}$ dan $\mathrm{S}$, (3) meningkatkan kemampuan tanah mengikat air (4) memperbesar kapasitas tukar kation (KTK) dan (5) mengaktifkan mikroorganisme. Beberapa penelitian menunjukkan bahwa pemberian bahan organik dan pemberian pupuk anorganik dapat meningkatkan $\mathrm{pH}$ tanah, $\mathrm{N}$-total, P-tersedia dan K-tersedia di dalam tanah, kadar dan serapan hara N, P, dan K tanaman, dan meningkatkan produksi tanaman jagung (Djuniwati et al ,2003; Banuwa et al., 2003), serta meningkatkan produksi kedelai (Hermawan, 2002).

Penambahan bahan organik yang berasal dari sisa tanaman dan kotoran hewan selain menambah bahan organik tanah juga memberikan kontribusi terhadap ketersediaan hara $\mathrm{N}, \mathrm{P}$, dan $\mathrm{K}$, serta mengefiensienkan penggunaan pupuk anorganik. Bahan organik dari jenis kotoran hewan (pupuk kandang) umumnya mudah terurai karena $\mathrm{C} / \mathrm{N}$ rasio yang rendah. Selain itu, penggunaan bahan organik (pupuk kandang) secara ekonomis murah, mudah diperoleh dan tanpa pendekatan teknologi yang tinggi sehingga relatif mudah dijangkau oleh petani.

Inceptisol Temate adalah tanah yang memiliki Corganik, N-total, P-tanah dan KTK tanah yang rendah, sehingga berdampak pada terbatasnya suplai hara yang dibutuhkan tanaman untuk menopang pertumbuhan dan produksi tanaman yang optimal. Oleh karena itu, penelitian ini bertujuan untuk mengetahui pengaruh dosis bahan organik dan pupuk N, P, K terhadap serapan hara dan produksi tanaman jagung di Inceptisol Ternate. Hipotesis dari penelitian ini adalah terdapat interaksi antara dosis bahan organik dan pupuk N, P, K terhadap serapan hara dan produksi tanaman jagung di Inceptisol Ternate.

\section{BAHAN DAN METODE}

Percobaan lapang dilaksanakan di Kelurahan Maliaro kecamatan Ternate Selatan, kota Ternate, sedangkan analisis tanah dan tanaman di laboratorium Kimia dan Kesuburan Tanah Departemen IImu Tanah dan Sumber Daya Lahan Fakultas Pertanian Institut Pertanian Bogor, yang berlangsung dari bulan Januari 2007 sampai Desember 2007. Karakteristik tanahnya disajikan pada Tabel 1.

Bahan yang digunakan terdiri dari bahan organik (pupuk kandang ayam), dan pupuk anorganik (urea, SP-36, dan $\mathrm{KCl}$ ). Benih tanaman jagung yang digunakan varietas 
bisi-2. Pupuk kandang yang digunakan adalah kotoran ayam yang bercampur dengan serbuk gergaji pada alas kandang ayam, dengan ciri kimia yang tertera pada Tabel 2.

Tabel 1. Hasil Analisis Kimia dan Fisik Tanah

\begin{tabular}{lcc}
\hline \multicolumn{1}{c}{ Jenis analisis } & $\begin{array}{c}\text { Hasil } \\
\text { analisis }\end{array}$ & Kriteria \\
\hline pH $\mathrm{H}_{2} \mathrm{O}(1: 1)$ total $(\%)$ & 6.02 & agak masam \\
C-organik (\%) & 0.13 & rendah \\
P-tersedia (ppm) & 1.85 & rendah \\
Kation dapat ditukar & & sedang \\
(me/100 g) & 11.77 & \\
$\mathrm{Ca}$ & 2.93 & tinggi \\
$\mathrm{Mg}$ & 1.07 & tinggi \\
$\mathrm{K}$ & 0.43 & sangat tinggi \\
$\mathrm{Na}$ & $\mathrm{tr}$ & sedang \\
$\mathrm{Al}$ & 0.08 & - \\
$\mathrm{H}$ & 16.28 & rendah \\
$\mathrm{KTK} \mathrm{efektif}$ & 99.5 & sedang \\
$\mathrm{KB}(\%)$ & 12.68 & sangat tinggi \\
$\mathrm{Fe}(\mathrm{ppm})$ & 2.76 & tinggi \\
$\mathrm{Cu}(\mathrm{ppm})$ & 24.76 & rendah \\
$\mathrm{Zn}(\mathrm{ppm})$ & 2.72 & tinggi \\
$\mathrm{Mn}(\mathrm{ppm})$ & & rendah \\
Tekstur Tanah & 39.94 & \\
$\mathrm{Pasir}(\%)$ & 37.90 & lempung liat \\
Debu (\%) & 22.16 & berpasir \\
Liat (\%) & & \\
\hline
\end{tabular}

Tabel 2. Ciri Kimia Bahan Organik (kotoran ayam)

\begin{tabular}{ccc}
\hline Jenis & Metode Analisis & Hasil \\
Analisis & Kjeldahl & 2.16 \\
\hline $\mathrm{N}(\%)$ & Walkley dan Black & 4.15 \\
$\mathrm{C}(\%)$ & Perhitungan & 1.92 \\
$\mathrm{C} / \mathrm{N}$ & Pengabuan Basah & 1.87 \\
$\mathrm{P}(\%)$ & Pengabuan Basah & 4.12 \\
$\mathrm{~K}(\%)$ & \\
\hline
\end{tabular}

Hasil analisis fisik tanah (Tabel 1) menunjukkan bahwa tekstur tanah termasuk klas tekstur lempung liat berpasir, sedangkan sifat kimia tanah menurut Kriteria Pusat Penelitian Tanah (1983), kemasaman tanah termasuk agak masam, $\mathrm{N}$-total rendah, $\mathrm{C}$-organik rendah, $\mathrm{P}$-tersedia sedang, Ca-dd dan $\mathrm{Mg}$-dd termasuk tinggi, $\mathrm{K}$-dd sangat tinggi, Na-dd sedang, Al-dd tidak terukur, KTK efektif sedang, persen kejenuhan basa sangat tinggi. Selanjutnya, ciri kimia bahan organik menunjukkan bahan yang mengandung kadar hara $\mathrm{N}, \mathrm{P}$, dan $\mathrm{K}$, serta sudah matang karena nisbah $\mathrm{C} / \mathrm{N}$ rendah (Tabel 2).

Percobaan ini menggunakan Rancangan Acak Kelompok Faktorial yang terdiri dari dua faktor. Faktor Pertama adalah dosis bahan organik $(0,20$, dan 40 ton/ha), yang kemudian dinyatakan sebagai $B_{0}=$ Tanpa bahan organik, $B_{1}=20$ ton $/ \mathrm{ha}, B_{2}=40$ ton ha. Faktor kedua adalah dosis pupuk $N P K\left(F_{1}, F_{2}\right.$, dan $F_{3}$, yang setara dengan $0.5 \mathrm{x} ; 1 \mathrm{x}$, dan $1.5 \mathrm{x}$ dosis anjuran). Dosis anjuran untuk tanaman jagung adalah $200 \mathrm{~kg}$ urea, $200 \mathrm{~kg} \mathrm{~kg} \mathrm{SP} 36$, dan $100 \mathrm{~kg} \mathrm{KCl}$. Dengan demikian rasio dosis pupuk anorganik untuk masing-masing perlakuan adalah sebagai berikut : $F_{1}$ $=100: 100: 50 ; F_{2}=200: 200: 100 ;$ dan $F_{3}=300: 300$ : 150.

Analisis data menggunakan analisis variance, dan untuk perlakuan yang memberikan pengaruh nyata maka dilanjutkan dengan Uji Beda Nyata Jujur $\alpha 0.05$.

\section{Pelaksanaan Penelitian}

Lahan yang digunakan sebelumnya dibersihkan dari gulma, kemudian dicangkul dan digaru sampai rata, dibuat bedengan dengan ukuran $4 \times 3 \mathrm{~m}^{2}$, jarak antara bedengan $40 \mathrm{~cm}$ yang berfungsi juga sebagai saluran drainase.

Penanaman tanaman dengan sistem tugal dan setiap lubang tugal diisi 2 benih jagung, dengan jarak tanam 80 $\mathrm{cm} \times 40 \mathrm{~cm}$. Pemberian bahan organik (bahan organik) dilakukan 1 minggu sebelum tanam (MST). Cara aplikasi bahan organik dilakukan pada larikan tanaman, Pemupukan $\mathrm{N}$ (urea) diberikan 2 kali yaitu masing-masing $1 / 2$ dosis pada saat tanam dan umur 14 HST, pemupukan $P$ dan K diberikan sekaligus pada saat tanam. Cara aplikasi pupuk dilakukan secara tugal pada sisi kiri atau kanan tanaman (berjarak $5 \mathrm{~cm}$ dari lubang tanam). Pemeliharaan tanaman meliputi; penyiangan, penyulaman, pembumbunan, penyiraman, dan pengendalian hama penyakit. Panen dilakukan pada saat tanaman jagung berumur 80 hari setelah tanam. Penentuan tanaman sampel dilakukan secara acak dan dipilih sebanyak 7 tanaman sampel/petak.

Parameter tanaman yang diamati adalah :

1. Tinggi tanaman, diukur dari pangkal batang hingga ujung daun tertinggi dan jumlah daun. Pengamatan dilakukan pada umur 14, 28 dan 42 HST.

2. Bobot basah tongkol dengan klobot dan tongkol tanpa klobot, bobot basah tongkol ditimbang pada saat panen, bobot kering tongkol dan bobot kering biji jagung ditimbang setelah dikeringudarakan selama 3 hari.

3. Analisis kadar dan serapan $N, P$, dan $K$ daun jagung.

4. Analisis tanah awal meliputi : $\mathrm{pH} \mathrm{H}_{2} \mathrm{O}, \mathrm{N}$-total, $\mathrm{P}$ tersedia, P-total, Ca-dd, Mg-dd, K-dd, Na-dd, Al-dd, H-dd, KTK efektif, Kejenuhan Basa (KB) dan tekstur tanah.

5. Analisis tanah setelah panen adalah : $\mathrm{pH}_{2} \mathrm{O}, \mathrm{N}$-total, P-tersedia, dan K-tersedia.

\section{HASIL DAN PEMBAHASAN}

\section{Pertumbuhan Jagung}

Perlakuan kombinasi bahan organik dan pupuk anorganik (NPK) tidak berpengaruh nyata terhadap tinggi tanaman jagung pada umur 14, 28 dan 42 HST. Pengaruh bahan organik dan pupuk anorganik pada rataan tinggi tanaman disajikan pada Gambar 1. 

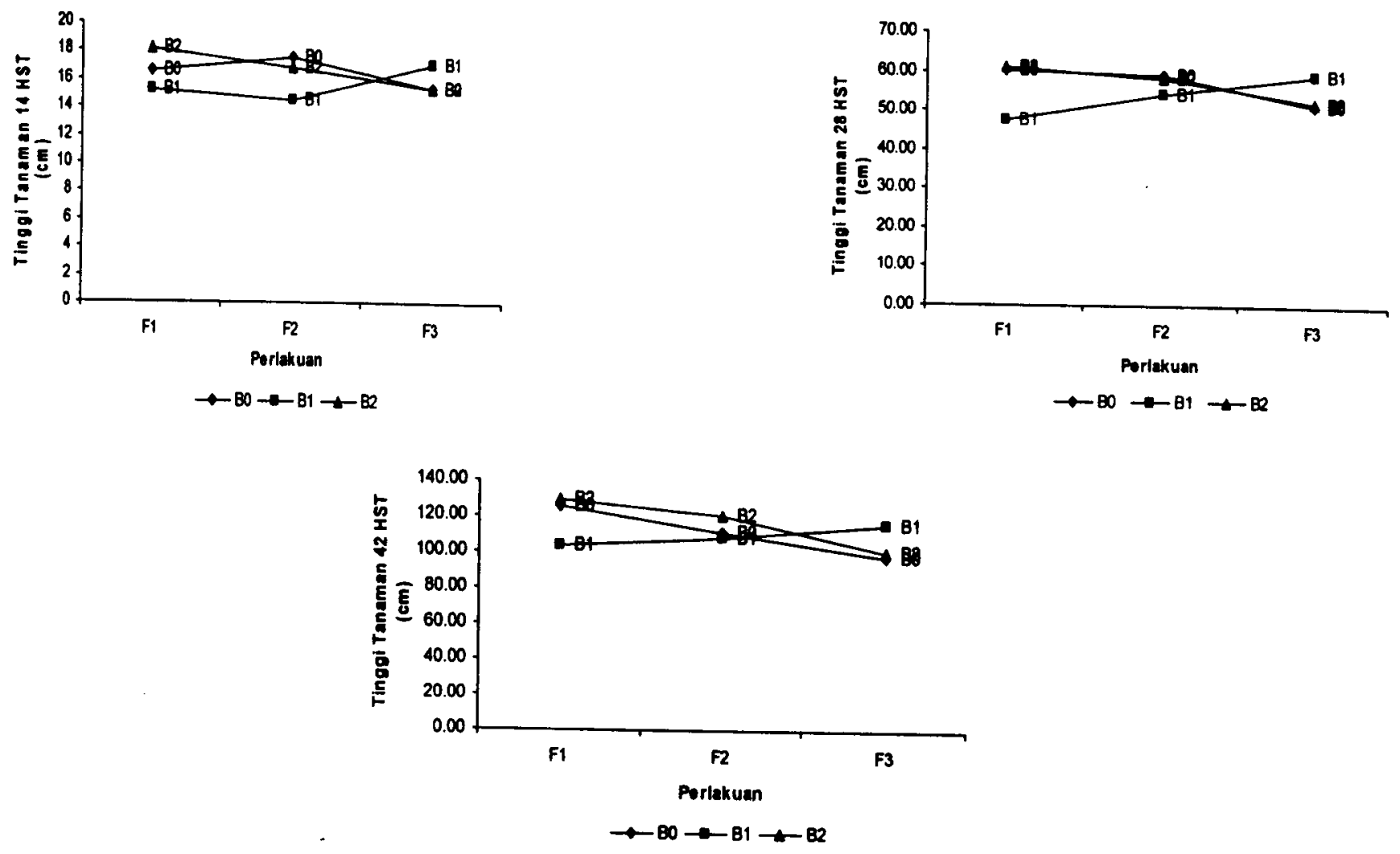
Gambar 1. Pengaruh Bahan Organik (B) dan Pupuk Anorganik (NPK) (F) pada Rataan Tinggi Tanaman Jagung pada Umur 14, 28, dan 42
HST

Gambar 1 menunjukkan bahwa tinggi tanaman pada umur 14,28 dan 42 HST perlakuan kombinasi bahan organik dan pupuk NPK $\left(B_{2} F_{1}\right)$ cenderung memiliki tinggi tanaman tertinggi dibandingkan dengan perlakuan kombinasi lainnya. Demikian juga perlakuan kombinasi bahan organik dan pupuk NPK tidak berpengaruh nyata terhadap jumlah daun pada umur 14 dan 28 HST. Pengaruh bahan organik dan pupuk anorganik pada rataan jumlah daun disajikan pada Gambar 2.
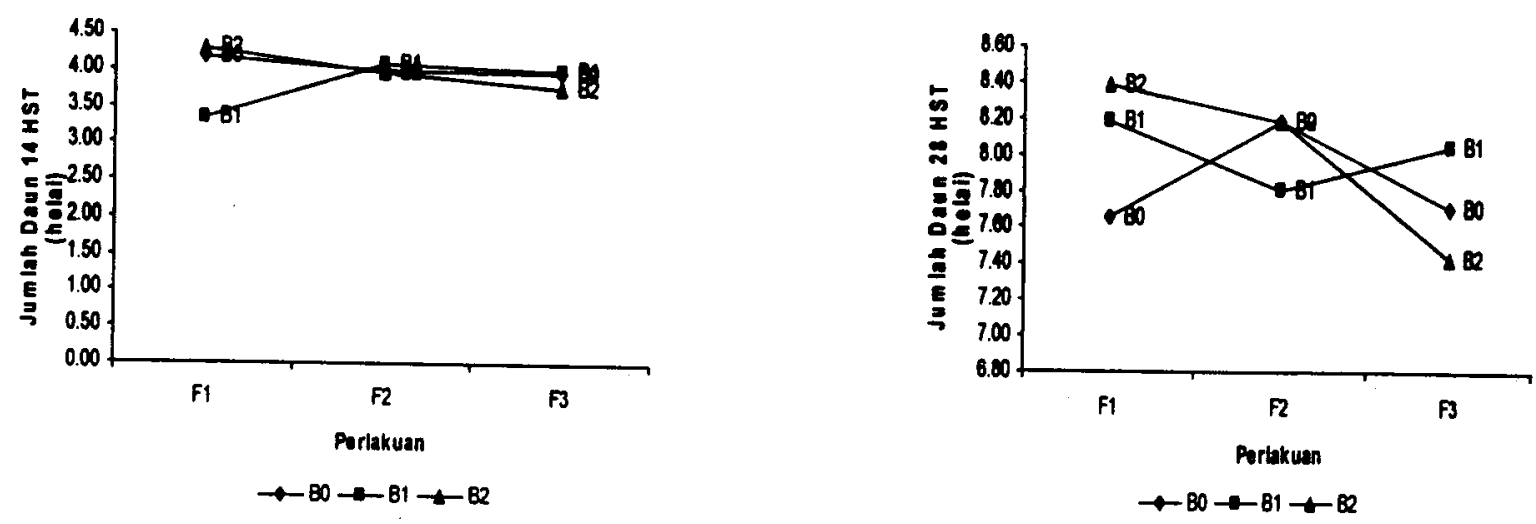

Gambar 2. Pengaruh Bahan Organik dan Pupuk Anorganik (NPK) terhadap Rataan Jumlah Daun Jagung Pada Umur 14 dan 28 HST

Gambar 2 menunjukkan bahwa rataan jumlah daun pada umur 14 dan 28 HST pada perlakuan kombinasi bahan organik dan pupuk NPK $\left(B_{2} F_{1}\right)$ juga cenderung memiliki jumlah daun terbanyak dibandingkan dengan perlakuan kombinasi lainnya. Namun, pada umur pengamatan 42 HST perlakuan kombinasi bahan organik dan pupuk NPK berpengaruh nyata, dan uji lanjutnya disajikan pada Tabel 3. 
Tabel 3. Pengaruh Bahan Organik dan Pupuk NPK terhadap Jumlah Daun Jagung pada Umur 42 HST (helai)

\begin{tabular}{cccc}
\hline \multirow{2}{*}{ Bahan organik } & \multicolumn{3}{c}{ Pupuk N P K } \\
\cline { 2 - 4 } & $F_{1}$ & $F_{2}$ & $F_{3}$ \\
\hline$B_{0}$ & $9.95 \mathrm{~b}$ & $9.33 \mathrm{bc}$ & $8.95 \mathrm{c}$ \\
$\mathrm{B}_{1}$ & $9.23 \mathrm{bc}$ & $12.33 \mathrm{a}$ & $9.04 \mathrm{bc}$ \\
$\mathrm{B}_{2}$ & $9.95 \mathrm{~b}$ & $9.95 \mathrm{~b}$ & $9.62 \mathrm{bc}$ \\
\hline BNJ $\mathrm{a} 0.05$ & 0.99 & & \\
\hline
\end{tabular}

Keterangan : Angka yang diikuti oleh huruf yang sama pada kolom yang sama tidak berbeda nyata pada uji BNJ dengan taraf $5 \%$. $B_{10}$ : tanpa bahan organik; $B_{1}: 20$ ton/ha: $B_{2}: 40$ ton/ha $F_{1}: 0.5 \times$ dosis anjuran; $F_{2}: 1 \times$ dosis anjuran; $F_{3}: 1.5 \times$ dosis anjuran

Tabel 3 menunjukkan bahwa pada perlakuan bahan organik (B), baik B0, $B_{1}$, maupun $B_{2}$, penambahan pupuk NPK $F_{3}$ cenderung menurunkan jumlah daun, dan perlakuan kombinasi $B_{1} F_{2}$ menghasilkan jumlah daun terbanyak dan nyata lebih tinggi daripada perlakuan kombinasi lainnya. Hasil ini berhubungan dengan pengaruh bahan organik dan anorganik (NPK) pada parameter tinggi tanaman. Hal ini menunjukkan bahwa pada dosis NPK $F_{2}$ yang disertai bahan organik dosis $B_{1}\left(B_{1} F_{2}\right)$ merupakan dosis optimal untuk menghasilkan tinggi tanaman dan jumlah daun tersebut.

\section{Produksi Jagung}

Hasil panen jagung menunjukkan bahwa perlakuan kombinasi bahan organik dan pupuk NPK berpengaruh nyata terhadap bobot basah tongkol jagung dengan klobotnya, dan uji lanjutnya disajikan pada Tabel 4.

Tabel 4. Pengaruh Bahan Organik dan Pupuk NPK terhadap Bobot Basah Tongkol Jagung dengan Klobotnya (kg/petak)

\begin{tabular}{cccc}
\hline \multirow{2}{*}{ Bahan organik } & \multicolumn{3}{c}{ Pupuk N P K } \\
\cline { 2 - 4 } & $F_{1}$ & $F_{2}$ & $F_{3}$ \\
\hline$B_{10}$ & $14.37 \mathrm{~b}$ & $13.33 \mathrm{~b}$ & $13.50 \mathrm{~b}$ \\
$\mathrm{~B}_{1}$ & $11.55 \mathrm{~b}$ & $20.07 \mathrm{a}$ & $14.88 \mathrm{~b}$ \\
$\mathrm{~B}_{2}$ & $15.95 \mathrm{~b}$ & $15.22 \mathrm{~b}$ & $13.32 \mathrm{~b}$ \\
\hline
\end{tabular}

BNJ a 0.05

Keterangan : Angka yang diikuti oleh huruf yang sama pada kolom yang sama tidak berbeda nyata pada uji BNJ dengan taraf $5 \%$. $B_{1}$ : tanpa bahan organik; $B_{1}: 20$ ton/ha; $B_{2}: 40$ ton/ha

$F_{1}: 0.5 \times$ dosis anjuran; $F_{2}: 1 \times$ dosis anjuran; $F_{3}: 1.5 \times$ dosis anjuran

Tabel 4 menunjukkan bahwa perlakuan $B_{1} F_{2}$ menghasilkan bobot basah tongkol dengan klobotnya tertinggi dan nyata lebih tinggi daripada perlakuan lainnya, sedangkan antara perlakuan lainnya tidak berbeda nyata. Sementara, bobot basah tongkol jagung yang tanpa klobot tidak dipengaruhi oleh perlakuan kombinasi bahan organik dan pupuk NPK, namun perlakuan bahan organik nyata mempengaruhi bobot basah tongkol tanpa klobot (Tabel 5).
Tabel 5. Pengaruh Bahan Organik terhadap Bobot Basah Tongkol Jagung tanpa Klobot

\begin{tabular}{cc}
\hline Bahan organik & Bobot basah tongkol tanpa klobol (kg/petak) \\
\hline$B_{1}$ & $9.69 \mathrm{~b}$ \\
$B_{1}$ & $10.16 \mathrm{a}$ \\
$\mathrm{B}_{2}$ & $10.37 \mathrm{a}$ \\
\hline BNJ a.0.05 & 0.21 \\
\hline Keterangan : & Angka yang diikuti oleh huruf yang sama pada kolom yang \\
& sama tidak berbeda nyata pada uji BNJ dengan taraf 5\% \\
& $\mathrm{B}_{0}:$ tanpa bahan organik; $\mathrm{B}_{1}: 20$ ton/ha; $\mathrm{B}_{2}: 40$ ton/ha
\end{tabular}

Tabel 5 menunjukkan bahwa perlakuan bahan organik 40 ton/ha $\left(B_{2}\right)$ tidak berbeda nyata dengan 20 ton/ha $\left(B_{1}\right)$, namun nyata lebih tinggi daripada tanpa bahan organik $\left(B_{0}\right)$. Selanjutnya, perlakuan kombinasi bahan organik dan pupuk NPK berpengaruh nyata terhadap bobot kering biji (Tabel 6).

Tabel 6. Pengaruh Bahan Organik dan Pupuk NPK terhadap Bobot Kering Biji Jagung (kg/petak)

\begin{tabular}{cccc}
\hline \multirow{2}{*}{ Bahan organik } & \multicolumn{3}{c}{ Pupuk NPK } \\
\cline { 2 - 4 } & $\mathrm{FI}$ & $\mathrm{F}_{2}$ & $\mathrm{~F}_{3}$ \\
\hline $\mathrm{B}_{\mathrm{a}}$ & $7.12 \mathrm{~b}$ & $7.25 \mathrm{bc}$ & $6.70 \mathrm{bc}$ \\
$\mathrm{B}_{1}$ & $6.19 \mathrm{c}$ & $9.40 \mathrm{a}$ & $8.57 \mathrm{a}$ \\
$\mathrm{B}_{2}$ & $8.38 \mathrm{a}$ & $8.13 \mathrm{~b}$ & $7.82 \mathrm{~b}$ \\
\hline
\end{tabular}

BNJ a 0.05

Keterangan : Angka yang diikuti olch huruf yang sama pada kotom yang sama tidak berbeda nyata pada uji BNJ dengan taraf $5 \%$

$B_{0}$ : tanpa bahan organik; $B_{1}: 20$ ton/ha; $B_{2}: 40$ ton/ha $F_{1}: 0.5 \times$ dosis anjuran; $F_{2}: 1 \times$ dosis anjuran; $F_{3}: 1.5 \times$ dosis anjuran

Tabel 6 menunjukkan bahwa pada perlakuan bahan organik $B_{0}$ dan $B_{2}$, penambahan pupuk anorganik NPK cenderung menurunkan bobot kering biji jagung, namun pada perlakuan bahan organik $B_{1}$, penambahan pupuk NPK nyata meningkatkan bobot kering biji jagung. Perlakuan $B_{1} F_{2}, B_{1} F_{3}, B_{2} F_{1}$ dan $B_{2} F_{2}$ menghasilkan bobot kering biji nyata lebih tinggi daripada perlakuan lainnya, dan perlakuan kombinasi $B_{1} F_{2}$ cenderung lebih tinggi daripada perlakuan $B_{1} F_{3}, B_{2} F_{1}$, dan $B_{2} F_{2}$, serta nyata lebih tinggi daripada perlakuan lainnya. Selanjutnya, pengaruh bahan organik dan pupuk anorganik NPK tidak berpengaruh terhadap bobot kering tongkol. Walaupun demikian, perlakuan $B_{1} F_{2}$ cenderung memiliki rataan bobot kering tongkol yang lebih tinggi dibandingkan dengan perlakuan lainnya (Gambar 3).

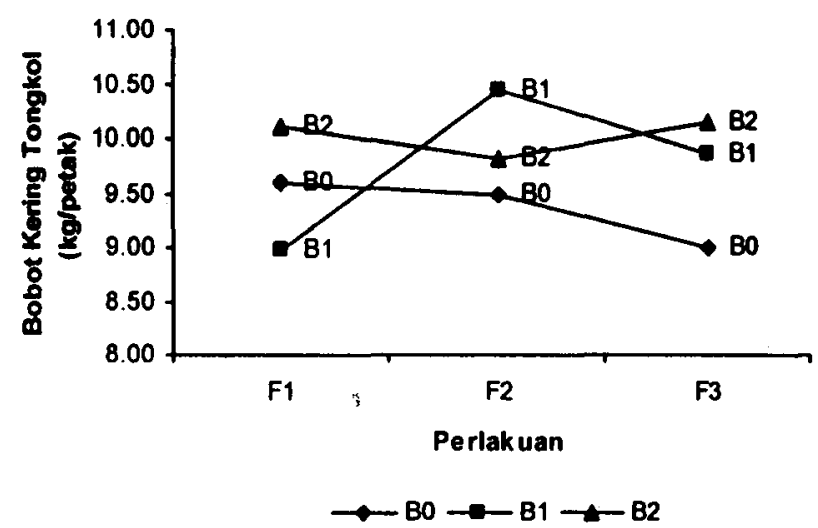

Gambar 3. Pengaruh Bahan Organik dan Pupuk Anorganik (NPK) pada Bobot Kering Tongkol Jagung 


\section{Kadar Hara Tanaman Jagung dan Tanah}

Perlakuan kombinasi bahan organik dan pupuk NPK tidak berpengaruh nyata pada kadar $\mathrm{N}$-tanaman. Namun sebagai perlakuan tunggal, bahan organik berpengaruh nyata terhadap kadar N-tanaman (Tabel 7).

Tabel 7. Pengaruh Bahan Organik pada Kadar N-Tanaman

\begin{tabular}{cc}
\hline Bahan organik & Kadar N-tanaman (\%) \\
\hline $\mathrm{B}_{0}$ & $1.086 \mathrm{c}$ \\
$\mathrm{B}_{1}$ & $1.264 \mathrm{a}$ \\
$\mathrm{B}_{2}$ & $1.147 \mathrm{~b}$ \\
\hline BNJ $\alpha .05$ & 0.034 \\
\hline
\end{tabular}

Keterangan : Angka yang diikuti oleh huruf yang sama pada kolom yang sama tidak berbeda nyata pada uji BNJ dengan taraf $5 \%$. $B_{0}$ : tanpa bahan organik; $B_{1}: 20$ ton/ha: $B_{2}: 40$ ton/ha

Tabel 7 menunjukkan bahwa perlakuan bahan organik 20 ton/ha $\left(B_{1}\right)$ menghasilkan kadar $\mathrm{N}$-tanaman tertinggi dan nyata lebih tinggi dibandingkan dengan kedua perlakuan lainnya, dan pengaruh bahan organik 40 ton/ha $\left(B_{2}\right)$ nyata lebih tinggi daripada perlakuan tanpa bahan organik $\left(B_{0}\right)$.

Sementara itu, perlakuan kombinasi bahan organik dan pupuk NPK tidak berpengaruh nyata terhadap kadar Ntanah, dan rataan kadar $\mathrm{N}$-tanah pengaruh bahan organik dan pupuk NPK disajikan pada Gambar 4. Pada gambar tersebut terlihat bahwa pengaruh perlakuan $B_{1} F_{1}$ tidak berbeda dengan perlakuan $\mathrm{B}_{2} \mathrm{~F}_{2}$, dan keduanya cenderung lebih tinggi daripada pengaruh perlakuan lainnya.

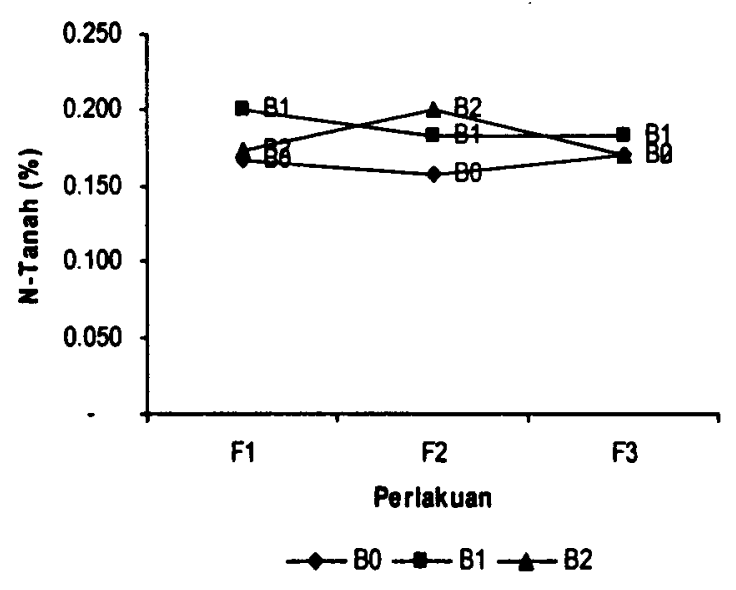

Gambar 4. Pengaruh Bahan Organik dan Pupuk NPK pada Kadar $\mathrm{N}$-Tanah

Kombinasi bahan organik dan pupuk NPK tidak berpengaruh terhadap kadar P-tanaman jagung. Namun secara tunggal, bahan organik berpengaruh nyata pada kadar P-tanaman (Tabel 8). Pola kadar P-tanaman pengaruh bahan organik serupa dengan kadar $N$-tanaman, yaitu perlakuan bahan organik 20 ton/ha $\left(B_{1}\right)$ menghasilkan kadar P-tanaman tertinggi dan nyata lebih tinggi daripada kedua perlakuan lainnya, dan pengaruh bahan organik 40 ton/ha $\left(B_{2}\right)$ nyata lebih tinggi daripada tanpa bahan organik $\left(B_{0}\right)$ (Tabel 8). Selanjutnya, perlakuan kombinasi bahan organik dan pupuk NPK tidak berpengaruh terhadap kadar P-tanah. Namun sebagai faktor tunggal, bahan organik berpengaruh nyata terhadap kadar P-tanah (Tabel 9).
Tabel 8. Pengaruh Bahan Organik pada Kadar P-Tanaman

\begin{tabular}{cc}
\hline Bahan organik & Kadar P-tanaman (\%) \\
\hline $\mathrm{B}_{0}$ & $0.269 \mathrm{c}$ \\
$\mathrm{B}_{1}$ & $0.356 \mathrm{a}$ \\
$\mathrm{B}_{2}$ & $0.298 \mathrm{~b}$ \\
\hline BNJ $\alpha 0.05$ & 0.012 \\
\hline
\end{tabular}

Keterangan : Angka yang diikuti oleh huruf yang sama pada kotom yang sama tidak berbeda nyata pada uji BNJ dengan taraf $5 \%$ $B_{0}$ : tanpa bahan organik; $B_{1}: 20$ ton/ha: $B_{2}: 40$ ton/ha

Tabel 9. Pengaruh Bahan Organik terhadap Kadar P-Tanah

\begin{tabular}{cc}
\hline Bahan organik & Kadar P-tanah (ppm) \\
\hline $\mathrm{B}_{0}$ & $20.54 \mathrm{c}$ \\
$\mathrm{B}_{1}$ & $27.03 \mathrm{~b}$ \\
$\mathrm{~B}_{2}$ & $30.64 \mathrm{a}$ \\
\hline BNJ a 0.05 & 1.69 \\
\hline
\end{tabular}

Keterangan : Angka yang diikuti oleh huruf yang sama pada kolom yang sama tidak berbeda nyata pada uji BNJ dengan taraf $5 \%$ $B_{0}$ : tanpa bahan organik; $B_{1}: 20$ ton/ha; $B_{2}: 40$ ton/ha

Tabel 9 menunjukkan bahwa pengaruh bahan organik 40 ton/ha $\left(B_{2}\right)$ memberikan kadar P-tanah tertinggi dan nyata lebih tinggi daripada kedua perlakuan lainnya, dan pengaruh bahan organik 20 ton/ha $\left(B_{1}\right)$ nyata lebih tinggi daripada tanpa bahan organik $\left(B_{0}\right)$.

Perlakuan kombinasi bahan organik dan pupuk NPK tidak berpengaruh nyata terhadap kadar K-tanaman jagung. Namun bahan organik berpengaruh nyata terhadap kadar $\mathbf{K}$ tanaman (Tabel 10). Kadar K-tanaman pengaruh perlakuan bahan organik 20 ton/ha $\left(B_{1}\right)$ tidak berbeda dengan bahan organik 40 ton/ha $\left(B_{2}\right)$ tetapi pengaruh kedua pertakuan tersebut nyata lebih tinggi daripada tanpa bahan organik $\left(B_{0}\right)$. Selanjutnya perlakuan kombinasi bahan organik dan pupuk NPK berpengaruh nyata terhadap kadar $\mathrm{K}$-tanah (Tabel 11). Tabel 11 menunjukkan bahwa perlakuan $B_{1} F_{2}$ memiliki kadar $\mathrm{K}$-tanah tertinggi, namun tidak berbeda nyata dengan perlakuan $\mathrm{B}_{2} \mathrm{~F}_{2}$ dan $\mathrm{B}_{2} \mathrm{~F}_{3}$. Pada umumnya pengaruh $B_{1} F_{2}$ mengandung kadar $K$-tanah lebih tinggi dibandingkan dengan perlakuan lainnya.

Tabel 10. Pengaruh Bahan Organik pada Kadar K-Tanaman

\begin{tabular}{cc}
\hline Bahan organik & Kadar K-tanaman (\%) \\
\hline $\mathrm{B}_{\mathrm{i}}$ & $2.82 \mathrm{~b}$ \\
$\mathrm{~B}_{1}$ & $3.44 \mathrm{a}$ \\
$\mathrm{B}_{2}$ & $3.37 \mathrm{a}$ \\
\hline BNJ a 0.05 & 0.10 \\
\hline
\end{tabular}

Keterangan : Angka yang diikuti oleh huruf yang sama pada kolom yang sama tidak berbeda nyata pada uji BNJ dengan taraf $5 \%$ $B_{0}:$ tanpa bahan organik; $B_{1}: 20$ ton/ha; $B_{2}: 40$ ton/ha

Tabel 11. Pengaruh Bahan Organik dan Pupuk NPK pada Kadar $\mathrm{K}-$ Tanah (me/100 $\mathrm{g}$ tanah)

\begin{tabular}{cccl}
\hline $\begin{array}{c}\text { Bahan organik } \\
\text { (ton/ha) }\end{array}$ & \multicolumn{4}{c}{ Pupuk N P K } \\
\cline { 2 - 4 } & $\mathrm{F}_{1}$ & $\mathrm{~F}_{2}$ & $\mathrm{~F}_{3}$ \\
\hline $\mathrm{B}_{0}$ & $0.45 \mathrm{~d}$ & $0.47 \mathrm{~d}$ & $\mathbf{0 . 6 0 \mathrm { c }}$ \\
$\mathrm{B}_{1}$ & $0.49 \mathrm{~d}$ & $0.71 \mathrm{a}$ & $0.56 \mathrm{~cd}$ \\
$\mathrm{~B}_{2}$ & $0.62 \mathrm{bc}$ & $0.65 \mathrm{abc}$ & $0.69 \mathrm{ab}$ \\
\hline
\end{tabular}

BNJ a 0.05

Keterangan : Angka yang diikuti oleh huruf yang sama pada kolom yang sama tidak berbeda nyata pada uji BNJ dengan taraf $5 \%$ $B_{11}$ : tanpa bahan organik; $B_{1}: 20$ ton/ha; $B_{2}: 40$ ton/ha 
Pada parameter $\mathrm{pH}$ tanah, bahan organik dan pupuk NPK tidak berpengaruh nyata dan rataannya disajikan pada Gambar 5 .

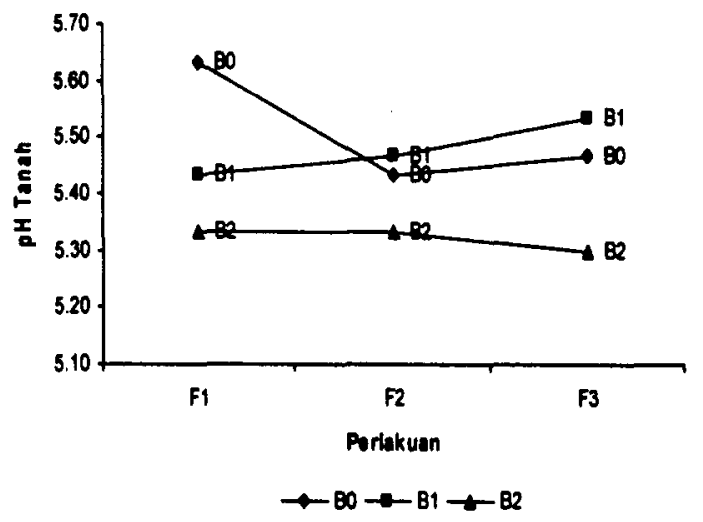

Gambar 5. Pengaruh Bahan Organik dan Pupuk NPK pada pH Tanah

Gambar 5 menunjukkan bahwa perlakuan bahan organik $\left(B_{2}\right)$ pada setiap perlakuan pupuk anorganik $\left(F_{1}, F_{2}\right.$ dan $F_{3}$ ) menunjukkan $\mathrm{pH}$ tanah cenderung lebih rendah

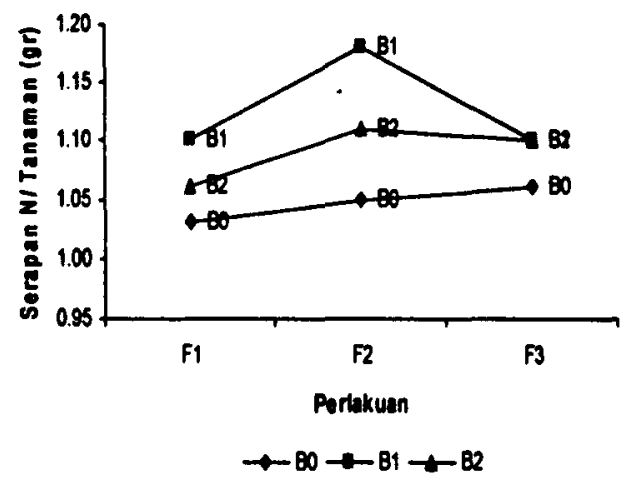

daripada perlakuan bahan organik $B_{0}$ dan $B_{1}$. Lebih rendahnya $\mathrm{pH}$ tanah pada perlakuan bahan organik diduga karena lebih banyaknya asam-asam organik yang dihasilkan dari bahan organik dosis tinggi ( $40 \mathrm{ton} / \mathrm{ha}$ ), dan di lain pihak diduga tanah mempunyai kapasitas buffer yang rendah, sehingga $\mathrm{pH}$ tanah menurun dengan penambahan ion $\mathrm{H}$ dari asam-asam organik yang dihasilkan bahan organik (pupuk kandang) tersebut.

\section{Serapan Hara N, P dan K Tanaman Jagung}

Perlakuan kombinasi bahan organik dan pupuk NPK tidak berpengaruh nyata terhadap serapan $\mathrm{N}$ dan $\mathrm{K}$ tanaman, dan rataannya disajikan pada Gambar 6. Gambar 6 menunjukkan bahwa serapan $\mathrm{N}$ dan $\mathrm{K}$ tanaman pada perlakuan $B_{1}$ dengan penambahan pupuk NPK $\left(F_{1}, F_{2}\right.$ dan $F_{3}$ ) cenderung lebih tinggi daripada perlakuan $B_{2}$, dan $B_{0}$ dengan penambahan pupuk NPK $\left(F_{1}, F_{2}\right.$ dan $\left.F_{3}\right)$ yang sama. Serapan $\mathrm{N}$ dan $\mathrm{K}$-tanaman tertinggi cenderung pada perlakuan yang sama yaitu pada perlakuan $B_{1} F_{2}$. Selanjutnya, serapan $P$ tanaman, dipengaruhi oleh perlakuan bahan organik, dan Uji lanjutnya disajikan pada Tabel 12.

Gambar 6. Pengaruh Bahan Organik dan Pupuk NPK pada Serapan N dan K Tanaman

Tabel 12. Pengaruh Bahan Organik pada Serapan P Tanaman

\begin{tabular}{cc}
\hline Bahan organik & Serapan $P(g /$ tanaman $)$ \\
\hline$B_{0}$ & $0.26 \mathrm{c}$ \\
$B_{1}$ & $0.33 \mathrm{a}$ \\
$B_{2}$ & $0.28 \mathrm{~b}$ \\
\hline BNJ $\alpha .0 .05$ & 0.01
\end{tabular}

Keterangan : Angka yang diikuti oleh huruf yang sama pada kolom yang sama tidak berbeda nyata pada uji BNJ dengan taraf $5 \%$. $B_{0}$ : tanpa bahan organik; $B_{1}: 20$ ton/ha: $B_{2}: 40$ ton/ha

Tabel 12 menunjukkan bahwa pola serapan P-tanaman sejalan dengan kadar P-tanaman, yaitu serapan $P$ pada perlakuan bahan organik 20 ton/ha $\left(B_{1}\right)$ tertinggi dan nyata lebih tinggi daripada perlakuan lainnya, sedangkan pengaruh bahan organik $B_{2}$ lebih tinggi daripada tanpa bahan organik $\left(B_{0}\right)$.

Hasil percobaan ini menunjukkan bahwa hampir pada semua parameter pengaruh perlakuan $B_{1} F_{2}$ umumnya menghasilkan hasil tertinggi dan beberapa parameter nyata lebih tinggi daripada perlakuan lainnya. Hasil yang nyata tertinggi pada parameter jumlah daun (42 HST), bobot basah tongkol dengan klobot, bobot kering biji, dan kadar $\mathrm{K}$-tanah, sedangkan parameter yang lain perlakuan $\mathrm{B}_{1} \mathrm{~F}_{2}$ cenderung lebih tinggi daripada perlakuan lainnya.

Lebih tingginya pengaruh perlakuan $B_{1} F_{2}$ menunjukkan bahwa perlakuan tersebut mampu menciptakan kondisi media tumbuh yang baik dan lebih baik daripada pengaruh perlakuan lainnya. Yusnaeni et al. (2004) membuktikan bahwa selama 2 musim tanam pertanaman jagung, kombinasi pupuk anorganik dan pupuk organik (kotoran ayam) dosis 20 ton/ha dapat memperbaiki produktivitas lahan, yaitu perbaikan dalam peningkatan $\mathrm{pH}$, kadar $\mathrm{N}$-total tanah, dan populasi cacing tanah sehingga produksi tanaman jagung juga meningkat. Selanjutnya, Purnomo (1995) menunjukkan bahwa pupuk kandang sapi 20 ton/ha pada tanah typic Halpudults mampu menurunkan bobot isi tanah $4.74 \%$, meningkatkan ruang pori total $2.11 \%$, dan meningkatkan air tersedia $4.98 \%$ bila dibandingkan dengan kontrol.

Hasil ini didukung oleh serapan $\mathbf{N}$ dan $\mathbf{K}$ tanaman pada perlakuan $B_{1} F_{2}$ cenderung tertinggi, dan pada serapan $P$ tertinggi pada perlakuan bahan organik 20 ton/ha $\left(B_{1}\right)$. 
Lebih tingginya serapan $N, P$, dan $K$ tanaman pada perlakuan $B_{1} F_{2}$ didukung oleh lebih tingginya produksi jagung yang ditunjukkan oleh bobot kering biji/petak pada perlakuan tersebut. Peranan hara $\mathrm{N}$ dalam memacu pertumbuhan vegetatif dan sintesa asam amino, dan kemudian Kalium berfungsi antara lain pada perkembangan akar, pembentukan karbohidrat (pati), dan mempengaruhi penyerapan unsur lain. Selanjutnya fosfat berperan penting dalam pembelahan sel, perkembangan akar, pembentukan bunga dan biji, penyusun RNA dan DNA dan menyimpan, memindahkan energi (ATP dan ADP) (Leiwakabessy et al., 2003; Marschner, 1986).

Produksi biji kering pada perlakuan kombinasi $\mathrm{B}_{1} \mathrm{~F}_{2}$ memiliki rataan tertinggi (7.83 ton/ha), kemudian diikuti oleh perlakuan kombinasi $\mathrm{B}_{1} \mathrm{~F}_{3}\left(7.14\right.$ ton/ha), $\mathrm{B}_{2} \mathrm{~F}_{1}(6.99$ ton/ha), $B_{2} F_{2}$ (6.78 ton/ha), $B_{2} F_{3}$ (6.51 ton/ha), $B_{0} F_{2}(6.48$ ton/ha), $B_{0} F_{1}$ (5.93 ton/ha), $B_{0} F_{3}$ (5.58 ton/ha) dan $B_{1} F_{1}$ (5.16 ton/ha).

Perlakuan bahan organik 40 ton/ha dengan pemupukan $\left(B_{2} F_{1}, B_{2} F_{2}\right.$ dan $\left.B_{2} F_{3}\right)$ umumnya memberikan pengaruh yang rendah pada beberapa parameter yang diamati. $\mathrm{Hal}$ ini diduga berhubungan dengan lebih rendahnya serapan hara $\mathrm{N}$ dan $\mathrm{P}$ tanaman, yang antara lain disebabkan oleh rendahnya $\mathrm{pH}$ tanah pada perlakuan tersebut (Gambar 5). Selain itu, tingginya kandungan Fe dalam tanah (Tabel 1) dan dengan $\mathrm{pH}$ tanah yang lebih masam (5.30-5.33) mengakibatkan ion $P$ difiksasi oleh $\mathrm{Fe}$ (Fe-P) sehingga $P$ tidak tersedia bagi tanaman. Hal ini ditunjang oleh rendahnya serapan $P$ pada perlakuan bahan organik $\left(B_{2}\right)$ (Tabel 12).

\section{KESIMPULAN DAN SARAN}

\section{Kesimpulan}

1. Pengaruh perlakuan $B_{1} F_{2}$ (bahan organik 20 ton/ha yang disertai pupuk NPK dengan dosis Urea 200 $\mathrm{kg} / \mathrm{ha}$, SP-36 $200 \mathrm{~kg} / \mathrm{ha}$ dan $\mathrm{KCl} 100 \mathrm{~kg} / \mathrm{ha})$ menghasilkan Jumlah daun jagung (42 HST), bobot basah tongkol dengan klobot, bobot kering biji jagung, dan kadar K-tanah tertinggi dan nyata lebih tinggi dibandingkan dengan perlakuan kombinasi lainnya.

2. Bobot basah tongkol tanpa klobot, kadar N-, P-, dan K-tanaman, serta serapan P-tanaman pada perlakuan bahan organik 20 ton/ha $\left(B_{1}\right)$ lebih tinggi dibandingkan dengan perlakuan bahan organik 40 ton/ha $\left(B_{2}\right)$ dan tanpa bahan organik $\left(B_{0}\right)$.

3. Serapan N P K jagung berkisar $31.41-39.39 \mathrm{~kg} \mathrm{~N} / \mathrm{ha}$, 6.03-12.54 kg P/ha, 37.5-41.70 kg K/ha.

4. Produksi jagung tertinggi yaitu 7.83 ton $/$ ha $\left(B_{1} F_{2}\right)$ dan terendah yaitu 5.16 ton/ha $\left(B_{1} F_{1}\right)$.

\section{Saran}

1. Dalam usaha budidaya tanaman jagung di Inceptisol Ternate dosis pupuk NPK anjuran sebaiknya dikombinasi dengan bahan organik yang setara dengan 20 ton pupuk kandang ayam/ha.

2. Perlu dilakukan penelitian lanjutan pada tanaman dan jenis tanah yang lain agar diperoleh dosis pupuk dan bahan organik yang optimal untuk produksi tanaman tersebut.

\section{DAFTAR PUSTAKA}

Banuwa, I. S., M. A. Pulung, dan M. Utomo. 2003. Pengaruh pemberian sisor (night soil) terhadap serapan NPK dan hasil tanaman jagung (Zea mays L). J. Tanah Trop., 16: 111-113.

Djuniwati, S., A. Hartono dan L. T. Indriyati. 2003. Pengaruh bahan organik (Pueraria javanica) dan fosfat alam terhadap pertumbuhan dan serapan $\mathrm{P}$ tanaman jagung (Zea moys) pada Andisol Pasir Sarongge. J. Tanah dan Lingkungan, 5: 16-22.

Hermawan, A. 2002. Pemberian kompos isi numen-abu sekam padi dan pupuk NPK terhadap beberapa karakteristik kimia tanah Ultisols dan keragaan tanaman kedelai. J. Tanah Trop., 15: 7-13.

Leiwakabessy, F. M., U. M. Wahjudin, dan Suwarno. 2003. Kesuburan Tanah. Jurusan Tanah. Fakultas Pertanian Institut Pertanian Bogor. Bogor.

Marschner, H. 1986. Mineral Nutrition of Higher Plants. Academic Press Harcourt Brace Jovanovich, Publishers, London Orlando San Diego, New York Austin Boston, sydney, Tokyo, Toronto. $674 \mathrm{pp}$.

Purnomo, C. A. 1995. Pengaruh Pemberian Abu Batubara dan Kotoran Sapi terhadap Perubahan Sifat Fisik Tanah dan Pertumbuhan Tanaman Jagung (Zea Mays) Hibrida pada Typic Hapludults di Gajrug. Skripsi Faperta. Jurusan Tanah. IPB.

Pusat Penelitian Tanah. 1983. Jenis dan Macam Tanah di Indonesia untuk Keperluan Survey dan Pemetaan Tanah Daerah Transmigrasi. Bogor.

Yusnaeni, S., M. A. S. Arif, J. Lumbanraja, S. G. Nugroho, dan M. Nonaka. 2004. Pengaruh jangka panjang pemberian pupuk organik dan inorganik serta kombinasinya terhadap perbaikan tanah masam Taman Bogo. J. Tanah Trop., 18: 155-162. 